\title{
Typhus in Buchenwald: Can the Story Be Told?
}

\author{
Ilana Löwy \\ (CERMES; Paris; ilanalowy@cnrs.fr) \\ ORCID: 0000-0001-6963-0578
}

\section{Fleck in Buchenwald}

In a 1948 Ludwik Fleck published an article "On experiments on human beings" which discussed the regulation of such experiments (Fleck 1948, 1052-1054). He published this text shortly after testifying at the Nuremberg trial about experiments which involved deliberate infection of healthy people with typhus (Flecks' testimony at the I.G. Farben trial in Nuremberg, February 12, 1948/2007). Fleck himself has a first-hand knowledge of German war research on this disease. He spent the last part of World War II in Block 50 in the Buchenwald camp, where he and other prisoners produced a typhus vaccine for the German army. Block 50 was in the immediate vicinity of the infamous block 46, where Nazi doctors - the same who were responsible for the vaccine production - conducted experiments on human beings. "Experiments" may be an inaccurate word. Buchenwald was a criminal endeavor of a criminal state in an insane world where no normal rules applied. The so-called "medical experiments" conducted in Block 46 had very distant relation to medical research, and very strong links with mass murder.

On the other hand, the insane world of the concentration camp contained elements which linked it to a more "conventional" science. Nazi doctors who conducted barbarous experiments on prisoners aspired to a conventional professional career. Some of these experiments - such as the tests of the efficacy of typhus vaccines, employed absolutely unacceptable means (read, assassination), but might have still produced some valid results. The prisoners who produced the typhus vaccine in Block 50 could have been executed at any moment, but in the meantime they had a relatively light workload, the possibility to borrow books from Jena University library, received letters and Red Cross packages, supplemented their camp food rations with stew made from the rabbits used in their experiments (after appropriate sterilization), and 
were able to move freely around the camp. They also conducted scientific discussions with their "employers". Nazi doctors used prisoners - those who worked for them on the production of the typhus vaccine and those who were used as "experimental subjects" (and "eliminated" if they survived the experiment) - as a means to accumulate publications, to acquire a reputation as scientists, and to advance their academic careers.

When Fleck arrived at Buchenwald in December 1943, he had already had a long trajectory as a victim of Nazi anti-Semitism, but also as somebody who survived and was able to keep his wife and son alive thanks to his skills as a scientist. In the Lvov ghetto, where he resided from December 1941 to December 1942, Fleck worked on the production of a typhus vaccine, using the urine of sick people as one of the sources of typhus antigens. ${ }^{1}$ In December 1942, Fleck, together with his family and several collaborators, was sent to work on the production of a typhus vaccine in the pharmaceutical company Laokoon located near Lvov. In January 1943, the whole group was deported to Auschwitz. At Auschwitz, Fleck was sent to the camp's hospital (Block 20), where he performed routine bacteriological tests. Later he worked with his family in the (in)famous Block 10, affiliated with the Hygiene Institute of the SS, again making mainly routine bacteriological and serological analyses. ${ }^{2}$

In December 1943, Fleck was transferred to the concentration camp Buchenwald, to work in Block's 50 laboratory on the production of a typhus vaccine. He persuaded his supervisors to let his teenage son work in the same laboratory. This laboratory was supervised by the Hygiene Institute of the SS in Berlin (and was under the responsibility of Joachim Mrugowsky), as were the experiments on humans conducted in Block 46. In his testimony for Yad Vashem, Fleck stated that the typhus vaccine was prepared in Block 50 in rickettsia-infected rabbits, using the method developed by Paul Giroud at the Pasteur Institute. The laboratory's director, Erwin Ding Schuler, trained under Giroud before the war, but was far from being a typhus expert: Fleck described him as an "ignoramus". Ding Schuler's inability to grasp the details of the production of the typhus vaccine, Fleck and other ex-prisoners explained, made possible a large-scale sabotage of this production. The prisoners fabricated a large quantity of worthless vaccine sent to the German army, and a small quantity of an efficient one, which was sent for control tests and distributed to prisoners inside the camp.

Fleck claimed that he had been at the origin of the sabotage action. The group at Block 50 was composed from lay persons and a few medical scientists, but - Fleck explained - until his arrival it had not included any expert on typhus. When he arrived at Block 50, he realized that the supposed infection of rabbits' lungs by rickettsiae had in fact been produced by an unrelated germ. He then revealed this to his fellow prisoners,

1 Fleck's testimony from 3 February, 1958, Yad Vashem Archive, Jerusalem (see also Weindling $2000,364-365)$. Some of the observations made in by him in the ghetto are included in papers he published after the war (Fleck 1946a, 307-309; Fleck 1946b, 663-666).

2 Fleck's autobiography from 1950 (reproduced in Werner, Zittel \& Schmaltz 2007, 315316). Fleck's curriculum vitae from August, 1957. Accessed at Das Ludwik Fleck Zentrum für Wissenschaftstheorie, Zürich, Thomas Schnelle's collection. 
and they collectively decided to continue the production of the worthless preparation, while at the same time making some "real" vaccine, to maintain the illusion that they were successful. ${ }^{3}$ Fleck provided a somewhat modified and stylized account of this experience in his 1946 article "Problems of the science of science". In 1950 he told a more straightforward account of the Buchenwald sabotage to a Polish journalist (Fleck 1946c, 335-336; English version in Cohen \& Schnelle 1986, 113-1274 ). According to the testimony of Eugen Kogon, a prisoner in Block 50, an important leader of the resistance movement (or rather one of the resistance movements) in Buchenwald, and Ding-Schuler's personal secretary, Fleck was not a "conspiratory" kind of person, and was not involved in the camp's complicated political games. He nevertheless played a central role in the sabotage of vaccine production (Schnelle 1986, 399-400). In 1948, Fleck proposed a typology of prisoners of concentration camps. He divided them into four categories; "organizers" - able to "organize" for themselves food and other means of subsistence; "muslims" - resigned, indifferent and leading a vegetative existence; "prominents" - open and hidden leaders; and "civilians" - people who maintained in the camp the same attitude they held before their arrest (Fleck on Tomaszewski's paper in 1948a, also reproduced in Werner et al. 2007, 296-297). Fleck probably saw himself as a "civilian", and might have been proud of his ability to behave normally in a highly abnormal situation.

\section{Conflict in Block 50: Fleck and Balachowsky}

In the article "Medical science in the light of Holocaust: Departing from a post-war article by Ludwik Fleck", Eva Hedfors proposes a new reading of Fleck's Buchenwald experience. This paper is part of a Hedfors' effort to debunk the (supposed) myth of Fleck as a great scientist. According to Hedfors, Fleck was not brought to Buchenwald as a specialist for the production of a typhus vaccine, but in order to perform the Weil-Felix test on prisoners submitted to medical experiments in Block 46 (the Weil-Felix test detects antibodies for the etiological agent of typhus, Rickettsia provazekii, and confirms the diagnosis of this disease). ${ }^{5}$ She thereby explains that Fleck was directly involved in Ding Schuler's criminal activities. Hedfors has two sources to this allegation: 1. an accusation made by Fleck's co-worker, Alfred Balachowsky, and 2. data provided by Fleck himself in an article he published in 1946 (Fleck 1946a). "The post war accusations that Fleck

3 Fleck's testimony for Yad Vashem.

4 Fleck's aim in this article was to demonstrate that "scientific facts" are produced by a "thoughtcollective", not to tell what happened at Block 46. The story of the production of a typhus vaccine at a concentration camp was modulated to fit this demonstration (Lutowski 1950/1986, 317-319).

5 In the winter of 1941-1942, Fleck was sent by Germans to work on the production of a typhus vaccine in the Lacoon factory near Lvov. It is thus highly probable that he was known to the Germans as an expert in this domain, and was brought to Buchenwald to help with vaccine production. The manufacture of an typhus vaccine was a delicate and complex endeavor. Any competent laboratory technician could have performed a routine Weil-Felix test . 
was involved in Ding-Schuler's murderous experiments on typhus," Hedfors explains,

are based on the testimony given during the Nuremberg Medical Trial by Alfred Balachowsky, professor of entomology at the Pasteur Institute, who was one of the former prisoners in Bloc 50. These accusations are reinforced by Fleck's own publication. Accordingly, it seems likely that Fleck's activities not only involved extended tests on prisoners that often proved to be fatal for subjects, but that his pursuits contravened the prisoners' rule of never reporting any personal observations on make suggestions to Ding Schuler who was always asking for such information (Hedfors 2008, 270).

Hedfors' conclusion is that: "blinded by his commitment to scien-
ce, he $\{$ Fleck $\}$ indulged in faulty science" (Hedfors 2008, 278)

A careful reading of Fleck's 1946 paper does not support Hedfors' claims. The topic of this paper is "antigenic drift", that is, the appearance of anti-Proteus antibodies (a positive Weil-Felix test) in the blood of healthy people. ${ }^{8}$ One table in this paper compares sera from 300 healthy and 200 infected people, and mentions experiments conducted in Lwow, Auschwitz and Buchenwald. Hedfors argues that Fleck's statement that he studied sera from non-infected people indicates that he used sera from Buchenwald prisoners, and is therefore a positive proof that Fleck actively participated in Ding Schuler's experiments in Block 46. In Auschwitz, Fleck worked in a routine analysis laboratory, where he had ample access to sera from normal and typhus infected people from numerous countries. ${ }^{9}$ Hedfors' allegations were accordingly refuted by a large group of Fleck scholars (Amsterdamska, Bonah, Borck et al. 2008, 937-944).

Hedfors alleged that Fleck actively participated in Ding Schuler's murderous experiments. Balachowsky's original accusation was decidedly less severe: Fleck, he maintained, discussed serology with Ding Schuler, and might have provided him an idea for his studies. François Bayle's book Croixgamme contre caducée (1950) quotes Balachowsky's testimony:

6 Balachowsky blamed Fleck for initiating experiments on humans in an interview in Francois Bayle's book Croix gammée contre caducée. His testimony during the Nuremberg trial did not mention Fleck. The references in Hedfors' paper seems to indicate that she did not attempt to check the accuracy of Balachowsky's accusations (or rather single accusation) against Fleck, did not read Balachowsky's Buchenwald diaries, and was not familiar with Fleck's detailed answer to Balachowsky's claims.

7 Paul Weindling's article "The Scientist as Survivor: Ludwik Fleck and the Holocaust" (Weindling $2001,85-96$ ) is an example of lucid, scholarly, sound and compassionate treatment of the same subject.

8 The Weil-Felix test is based on a (probably accidental) cross reaction between antibodies against the etiological agent of typhus, Rickettsia provazekii (impossible to cultivate in a test tube, and thus difficult to use in standard agglutination tests) and the enteric bacillus Proteus X.

9 Dr Anna Seaman from Lvov, who worked with Fleck in Auschwitz's recalled: "we shared the same fate, first in the Lvov prison at the Lacki street, and then in the camp, where we were put in Block 10, the experimental block. In the laboratory, we all worked under Fleck's orders. I made serological tests, the Wassermann reaction, on the serum of prisoners scheduled to be transferred to other camps. The sabotage consisted in preventing a positive result that attested that a prisoner suffered from syphilis or typhus from reaching the SS, because the meaning of such a result was the prisoner's death." Anna Seaman's testimony, accessed in Thomas Schnelle Archive, Das Ludwik Fleck Zentrum, Zurich, TSA, D 14/1. 
Professor Ludwik Fleck, a Polish-Jewish political prisoner, deliberately told Schuler in July 1944 that he believed he had observed modification of serological reactions: the sudden increase in agglutination titer of the Weil-Felix reaction, $1 / 400$ to $1 / 800$, at the third and the fourth day of the disease. Schuler immediately sent a report to Leipzig asking for a permission to conduct new experiments, which was granted rapidly. September 6, 1944, twenty new subjects were inoculated in Block 46; serological observations were made daily. The Weil-Felix reaction was not specific; only two subjects had a positive reaction (Bayle $1950^{10}$ ).

Balachowsky added that 19 out of 20 inoculated prisoners died of typhus. ${ }^{11}$

Fleck's accuser, Alfred Serge Balachowsky (1901-1983) was trained as agronomist, and specialized in agricultural entomology. Before the war he worked at the French Institute for Agricultural Research (INRA). During the war, he played an important role in the Julite Resistance network linked with the British spying network Special Operation Executive (SOE) ${ }^{12}$ Arrested in June 1943, he was first sent to the Fresnes prison. His wife and his colleagues then persuaded the Pasteur Institute's director, Jacques Trefuël, to name him a member of the Institute, a status which, they believed, could help him to obtain better conditions during his imprisonment. This indeed was the case. Sent to the deadly Dora camp in late 1943, Balachowsky was transferred in May 1944 to Block 50, thanks to the intervention of the director of French National Library, Julien Cain, who told Ding-Shuler's collaborator, Walter Kummilscheim, about the presence of a Pasteur Institute expert in the camp. ${ }^{13}$

It is unlikely that Balachowsky, who had neither medical nor bacteriological training, had a leading role in the production of the typhus vaccine in Block 46. However, as an experienced laboratory worker, he probably participated in some aspects of this production and in other activities of the block's laboratory. Like other prisoners of Block 50, he enjoyed special privileges reserved to scientists: he received numerous food packages, corresponded with his family, wrote to the director of Pasteur Institute asking for scientific materials, read and commented on professional publications, enjoyed reading literary works, and even reported in his diary that he had seen a movie. ${ }^{14}$ In parallel, Balachowsky

10 Transl. from French to English by I. Löwy.

11 «Le professeur Ludwik Fleck interne politique polonais juif, indiqua délibérément à Schuler en juillet 1944 qu'il pensait observer des modifications dans les réactions sérologiques à l'occasion d'une élévation soudaine du taux d'agglutination dans la réaction de Weil Félix 1/400 à 1/800 au cours de la troisième et le quatrième jour de la maladie. Schuler envoya immediatement un rapport à Leipzig pour demander des nouvelles experiences qui furent autorisés très rapidement. Le 6 Septembre 1944, vingt nouveaux sujets furent innoculés au block 46, et des observations sérologiques furent faites jour par jour. La reaction de Weil-Felix ne s'est pas montré spécifique, deux sujets sur vingt l'ont presenté» (Bayle 1950, 1162).

12 Speech of Pierre Julite, head of the Julite resistance network, at the ceremony of handling the Academicien Sword to Alfred Balachowsky, January 14, 1972 (BAL/1).

13 Letter of Balachowsky's first wife, Emilie Morin-Balachowsky to Mr Dorst, of Academie Française, of 9 January, 1984 (BAL/1).

14 Balachowsky's Buchenwald diary includes details on his daily life in Block 50, many mundane (packages and letters received, novels read). It also recorded unusual events, like learning about the liberation of Paris (BAL/1). 
used his freedom to move around in Buchenwald and his close links with the camp's resistance network in order to collect information about Nazi crimes, undoubtedly a risky enterprise. He made detailed notes on executions, starvation, and experiments on humans. His important testimony at the Nuremberg trial was grounded in these notes. ${ }^{15}$

Balachowsky main achievement in Buchenwald, the one for which he was awarded the Grande Croix de la Resistance, was the saving (October 1944) of three officers of the resistance: the British commander Yeo-Thomas, another British resistance officer, Harry Peulevé, and the Frenchman Stéphane Hessel. Balachowsky's Croix de la Resistance citation did not provide details of this feat. They appear, however, in the British citation for the British Kings Medal for courage in the cause of freedom and in publications on the SOE network. Balachowsky, together with Erwin Kogon, persuaded Ding Schuler to save the British officers in order to be granted favors by the allies in the face of the increasingly probable defeat of Nazi Germany. Ding Schuler exchanged the identity of the SOE officers with three French prisoners of war dying from typhus in Block $46 .{ }^{16}$ The officers were transferred to Block 46 , where they waited until their "namesakes" died. Then they were given the Frenchmen's identities and smuggled out of Buchenwald (Foot 1966, 427-428; see also Hessel 1997 ${ }^{17}$ ).

In his testimony before the Nuremberg tribunal (29 January 1946) and in a later publication, Balachowsky described the experiment that may have led to his accusations against Fleck: "in July 1944, experiments on typhus were made in Block 46, to study the modifications of the serological reactions during the first stage of the illness. A sudden rise in the agglutination having been noticed, WF 1/400-1/800. On September 8 , twenty men were vaccinated and blood tests were taken daily to study their serological reactions. On September 20 four died, on September 21, eight died, on September 22 , five died. On October 11, only one man survived."18 In his testimony at Nuremberg he did not mention Fleck or any other prisoner. He blamed Fleck solely in his conversation with François Bayle, reproduced in the latter's book on Nazi human experiments.

Bayle's book was published in 1950, but Fleck learned about Balachowsky's accusations only in 1958, after his immigration to Israel. In a letter to a friend he expressed his hurt and added: "I have already a certificate from professor Waitz from Strasbourg, who worked in the same laboratory I did in Buchenwald. He was especially interested

15 Balachowsky's testimony, Nuremberg trial, 29.1.1946, available online: http://www.yale.edu/ lawweb/avalon/; also Balachowski (1965) and Balachowsky, ms., "Lest We Forget: Camps of Death in Germany" (BAL/1).

16 These prisoners were not victims of Ding Schuler's experiments but were infected accidentally with typhus in a different camp. Block 46, it seems, harbored not only prisoners subjected to experiments, but also some "normal" typhus patients isolated in this block, another possible source of Weil-Felix positive sera. These patients usually came from the outside the camp: typhus was not endemic in Buchenwald.

17 Hessel's testimony can be found online: http://www.hg.goe.ni.schule.de/projekte/dora/ jahrestag/shfz.doc. While Ding Schuler did the identity exchange, Kogon and Balachowsky were in constant contact with the jailed resistance officers, and kept them informed about the disease of their, "namesakes", and chances to be free. Ding Schuler committed suicide in prison in summer 1945.

18 Balachowsky, ms., "Lest We Forget: Camps of Death in Germany" (BAL/1). 
by experiments on humans and testified about them at the Nuremberg tribunal. Waitz states in his testimony that there was no doubt whatsoever about my behavior in $\mathrm{Bu}$ chenwald and my attitude towards the SS. He clearly affirms that I did not take part, directly or indirectly in any of these "experiments". He adds that "the prisoners respected me, and that I participated in the sabotage action against the Germans. (...) But the main point is that Balachowsky's claims do not make any sense at all. How can anybody take it seriously? (...) Why this calumny?"19 Fleck considered at first suing Balachowsky for slander, then decided against such an action. The most probable interpretation is that Balachowsky accused him of trying to impress Ding Schuler with his cleverness, and, in spite of unwritten codes of conduct at Block 50, provided information that might have inspired a new experiment. The accusation of irresponsible behavior, Fleck explained, is highly distressing, but is not a sufficient ground for a trial for slander. ${ }^{20}$

Fleck decided instead to publicly refute Balachowsky's accusation. He produced a lengthy document on this subject, destined to be published in the Polish journal Medical Weekly (Tygodnik Lekarski). In this text Fleck argued that Balchowsky's accusation was senseless, and showed a total ignorance of the serology of typhus. The observation that a Weil-Felix test may be positive in the early stages of typhus was not new. Ding Schuler used a textbook that affirmed that the Weil-Felix reaction can sometimes be positive as early as the $3^{\text {rd }}$ or $4^{\text {th }}$ day of infection. All experts know, however, that this an extremely rare event. Fleck explained that he does not remember discussing an early Weil-Felix reaction with Ding Schuler, but, on the other hand, he was not able to exclude the possibility that it might have happened. He and his colleagues had "numerous dangerous conversations" with Ding Schuler and his SS superiors. However, even if he did mention an early Weil-Felix reaction, he would surely not have proposed infecting twenty people in order to display such a reaction, because the probability of finding such a rare event in a small group was practically zero. No experienced serologist would ever propose such a meaningless experiment. Fleck added that Balachowsky's German was very poor and he was unable to follow a technical discussion between Fleck and Ding-Schuler. He must have therefore heard about Fleck's presumed proposal to conduct human experiments from another prisoner. However, Balachowsky was the only person who accused Fleck of improper behavior (Fleck 2007, 306-311) ${ }^{21}$.

Fleck proposed two possible explanations for Balchowsky's attitude: a personal animosity, and right-wing political views. Balachowsky, he argued, was always hostile to Fleck and resented the latter's superior standing in the laboratory's internal hierarchy.

19 Fleck to Barbara Narbutowicz, 14 June, 1958 (Werner, Zittel \& Schmaltz 2007, 346-347). Kogon confirmed that Fleck was considered among the prisoners in Block 50 as one of the best European experts on typhus, had an uncontested scientific authority on this issue, and played a key role in the sabotage of vaccine production. According to this testimony, Fleck was liked and trusted by his co-prisoners (Werner, Zittel \& Schmaltz 2007, 399-400).

20 Fleck to Narbutowicz, 3 September, 1958 (Werner, Zittel \& Schmaltz 2007, 348-349).

21 This text, found among the papers of professor Stanislaw Konopka, co-editor of Polish Medical Weekly, was never published. 
In his document Fleck mentioned a specific incident in which he rejected a vaccine prepared by Balachowsky because it was not sterile. A non-sterile batch of vaccine, Fleck explained, put the whole sabotage enterprise in danger. A careful verification of a problematic batch would have revealed that the vaccine was worthless. That this incident occurred is confirmed by an entry in Balachowsky's diary of 26 February, 1945: "balloon 10 liters broken by Fleck! The series 115 - 10,000 Reichmarks lost!"22. It is indeed not entirely improbable that Balachowsky, who held prominent place in the camp hierarchy thanks to his standing with the resistance, and who had recently been appointed a researcher at the Pasteur Institute (according to his wife, he was overjoyed when he learned about it in the Fresnes prison), resented being given orders by a "nobody" from Lvov.

Fleck claimed that Balachowsky held right wing views and disliked Jews. However, since he was writing in 1958, he did not say outright that Balachowsky was an anti-Semite, a term that could notbe employed in Poland at that time, especially by aJew who had emigrated to Israel, but employed the expression "fascist inclinations" instead. Indeed, Balachowsky's Buchenwald notes openly display his strong dislike of Jews: Balachowsky had written, e.g.,

January 24, 1945. An important convoy of Jews (5000) arrived from Auschwitz, nearly without any surveillance (...) The Volkssturm were carried on the Jews' shoulders; they elected to bring their jailers with them instead of eliminating them as the Poles and the Russian did. They are afraid of 'bolchewick' and have chosen to come back with the Germans. I saw this convoy, it is composed from tiny, degenerated individuals, plagued by eye sickness, bent into two, a totally dazed race characterized by small height (...) repulsive dirt of half-witted Jews (...) Physically hideous, abnormal eyes, huge ears, big noses, horrendous (...) a 15 years old boy asked somebody in the block to rip out golden teeth from the mouth of his dying father to be able to keep them - horrid scenes. ${ }^{23}$

\section{Who Performed the Weil-Felix Test?}

In 1958, Fleck explicitly rejected the claim that he had been responsible for performing the Weil-Felix reaction on sera of people infected with typhus in Block 46: "Balachowsky's fuzzy and exaggerated sentence may only mean that I drew Dr. Schuler's attention to the fact that in one case or a few cases the Weil-Felix reaction was already positive at the $3^{\text {rd }}$ or $4^{\text {th }}$ day of illness. However, I was not responsible for the Weil-Felix

22 Journal de Buchenwald (Balachowski, BAL/1), trans. by I. Löwy. From October 1944, entries in Balachowsky's journal were made in English. Fleck could not have known in 1958 about the existence of this journal, given to French National Library after Balachowsky's death in 1983.

23 «24.1.45. Convoi important des juifs (5000) arrives Auswitz (sic) presque pas gardés au départ (...) Volkssturm portes sur les épaules des juifs qui ont préfèré ramener leurs gardiens plutôt que de finir comme les polonais et les russes. Ont grand peur des « bolchewick » et préfèrent revenir avec les Allemands. Vu le convoi, renferme des êtres petits, dégénérés, mal aux yeux, courbes, race complètement abasourdie, caractérise par leur taille minuscule. (...). Saleté repoussante des juifs complètement abrutis. (...) Physiquement affreux, yeux anormaux, maigres et osseux, oreilles énormes, nez proéminent, affreux. (..) jeune garçon 15 ans a demande à block d'arracher les dents en or de son père qui était mourant pour ne pas les perdre - scènes affreuses,» Notes de Buchenwald (Balachowski, BAL/1). 
tests in the camp, but a French prisoner, René Morat. Balachowsky himself reported it on p. 1158 and p. 1163 of Bayle's book. Therefore, only Morat could have seen it, not me. It cannot be ruled out that one of the samples tested by Morat was positive already at day three or four, and Schuler might have asked if such a result is possible at all. I do not remember such an event, but it might have happened". ${ }^{24}$ In a testimony made by Fleck shortly after his liberation from Buchenwald, on returning from Buchenwald, in 1945, he provided, however, different information: "in Buchenwald I worked as a bacteriologist in the Hygiene Institute, together with professors of foreign universities. It is important to report what happened in Block 46. The access to this block was forbidden, only SS-men and German Kapo worked in that block. People were infected with typhus there; there were approximately 900 victims, and nearly 100\% mortality. The typhus strains were especially virulent. The Germans tried the effects of different vaccines on infected people. I know about it, because I received the blood of sick people in order to confirm the victim's disease. I did not know the name of the infected people, I received only test tubes with a serial number. When a series ended, I knew that the patient had died". 25

One possible explanation for the contradiction between Fleck's 1945 and 1958 statements is that in 1958, Fleck, who saw himself as a victim of vicious slander, feared that any admission of an involvement, however indirect, in Ding Schuler's experiments would aggravate his case. He therefore chose to deny that he performed the Weil-Felix reaction on blood of people deliberately infected with typhus. Another explanation may be that in 1945 Fleck wanted above all to provide first-hand testimony on the - then totally unknown - horrors of Nazi experiments on human beings. In order to make his argument more compelling he might have chosen to present knowledge he acquired through the observation of deeds of other prisoners as stemming from his own experience. It is also possible that the Weil-Felix test was usually performed by René Morat, but other prisoners, among them Fleck, performed it occasionally. Finally, Fleck might have gradually erased some of the more problematic aspects of his survival in Buchenwald from his memory, and had come to believe in an "edited" version, which placed an emphasis on sabotage and resistance. The latter hypothesis may be indirectly supported by the fact that (as far as I know) after 1945 Fleck did not mention that he had observed first-hand the consequences of murderous experiments on human beings.

In early 1948, Fleck was called as a witness at the Nuremberg trial, but he testified

24 L. Fleck, “On Buchenwald: Comment on F. Bayle’s book ..., citation p. 307. Fleck's 1946 paper does not deal with routine Weil-Felix tests (confirmation that a person is infected with Rickettsia provazekii), but with fine grained calibration of this test using several bacterial strains.

25 Fleck's statement was collected and transcribed in 1945, in the framework of a systematic collection of testimonies of surviving Jews by the Jewish community in Poland. Document 301/1139, Jewish Historical Institute, Warszawa (reproduced in Werner, Zittel \& Schmaltz 2007, 356-357). Fleck adds that his fellow prisoners, Dr. Marian Ciepielowski from Krakow, Dr. Mokowiczka from Prague, Professor Waitz from Strasburg, Professor Kirmann and Professor Balachowsky from Paris can attest to the exactitude of the facts he reported in his testimony. This testimony contradicts Hedfors' affirmation that, "Fleck does not pass any judgement on the science pursued in Buchenwald" (Hedfors 2008, 276). 
there as an expert on typhus, not as an ex-prisoner of Block $50 .{ }^{26} \mathrm{He}$ stated in his testimony that documents on typhus written by the German Health Ministry and scientific papers produced by Ding Schuler could not have originated in the observations of people who were naturally infected with this disease. ${ }^{27}$ When Fleck discussed his war experiences with a journalist in 1950, he did not mention directly witnessing experiments in Block 46, and he did not bring up this issue in his subsequent autobiographical sketches (Lutowski 1950). While Fleck did not testify at Nuremberg about first-hand knowledge of experiments on human beings, such knowledge was at the very center of Balachowsky's testimony at the Nuremberg trial. ${ }^{28}$ Balachowsky nevertheless stressed that he had no direct links whatsoever with these experiments: "my work consisted in manufacturing vaccine, and neither I nor any other prisoners in Block 50 could ever enter Block 46 and actually witness experiments. We knew what went on concerning the experiments only through the index cards which were sent from Block 46 to be officially registered in Block 50". ${ }^{29}$ On the other hand, the dramatic story of saving of lives of three resistance officers hidden on the first floor of Block 46 may indicate that Kogon and Balachowsky had a detailed knowledge of what was going on inside that block (Hessel 1997) ${ }^{30}$.

Assuming that several inmates of Block 46 indeed performed routine blood tests on the victims of Ding Schulers experiments, what other choice did they have? Balachowsky was very clear on this subject. When asked by the defender in the trial if he pitied the victims of Nazi experiments, he explains that that :"my pity was very great, but it was not a question of having pity or not; one had to carry out to the letter the orders that were given or be killed." ${ }^{31}$ Survival in Block 50, Paul Weidling pointed out, depended on prisoners' ability to prove that they faithfully accomplish the tasks they were

26 Fleck came back from Nuremberg deeply disgusted with German scientists' attempts to deny their involvement in Nazi crimes. Fleck to Ludwik Hirszfeld, 22 February, 1948 (reproduced in Werner, Zittel \& Schmaltz 2007, 334-335).

27 Flecks' testimony at the I.G. Farben trial in Nuremberg, February 12, 1948. I.G. Farben was one of the producers of typhus vaccines tested in Block 46. It is not clear if the choice of whether Fleck's testimony would involve only his professional expertise, and not his personal experience during the war, was the procurator's or his.

28 Among the documents presented at Nuremberg trial, together with Balachowsky's testimony were detailed data on 14 typhus infected prisoners (all died), including temperature charts and the results of the Weil-Felix test, copied by Waitz and Ciepielowski (a young Polish physician who worked in Block 50) from protocols signed by Ding Schuler during the few hours they had access to these papers in March 1945, just before the liberation of the camp. Document no. 859, from November 29, 1946. Photographs of these documents are available online:

http://nuremberg.law.harvard.edu/php/search.php

These same data were reproduced in an article by Waitz and Ciepielowsky $(1946,322-324)$ on human experiments.

29 Transcript, Balachowsky's testimony at the Nuremberg trial, 29 January 1946 (BAL/1).

30 Hessel reproduces letters he exchanged with Kogon during his stay in Block 46. This correspondence attests that Kogon knew very well who the French prisoners expected to die were -so that the resistance could take their identity and monitor their progress. The death of these prisoners meant survival for Hessel and his colleagues.

31 Transcription, Balachowsky's testimony at the Nuremberg trial (BAL/1). The French politician Edgar Faure noted in his memories that Balachowsky was accused in Nuremberg of collaboration in experiments on human beings. 
allocated and to demonstrate their scientific skills, all this under conditions of extreme coercion (Weindling 2009). Their tasks might have included routine laboratory tests on the blood of people deliberately infected with typhus. Inmates of Block 50 aspired to subvert the German war effort, help the resistance movement, bear witness to Nazi crimes and survive; Fleck also wanted to save his young son, who worked in Block 50's laboratory. It is reasonable to assume that in order to achieve these intermingled goals they were occasionally obliged to skate on very thin ice and to make morally complicated decisions. Immediately after the war, Fleck explained, many camp survivors were victims of "malicious gossip" (Fleck 2007). One of the aims of the glorification of politically visible survivors - especially those who, like Balachowsky, were celebrated as official heroes of the resistance movement - might have been to deflect accusations that they would have not stayed alive without occasionally compromising their moral integrity.

In spite of the abundance of testimonies of ex-prisoners of Block 50 in Buchenwald, the effort to uncover what "really" happened there between 1943 and 1945 may in vain. The historian's aspiration to find "facts and only facts" is akin to scientists' wish to uncover neutral and objective "scientific facts": an unattainable goal. ${ }^{32}$ The paucity of reliable data and the difficulty of uncovering strong causal links is not an excuse for lowering the standards of historical scholarship; it is a good reason to raise such standards. But perhaps some questions cannot be answered through historical research, however excellent. Other kinds of truth, such as artistic ones, may be better adapted to illuminate human behavior under extreme conditions.

\section{Exceptional and "Normal" Human Experiments}

Pleading for the stringent regulation of experiments on human beings, Fleck argued that such regulation is important, not only because of the recent horror of Nazi experimentation but also because such experiments were and are very frequent. They played an important role in the development of medical knowledge: "some classical heroes of modern medicine made such experiments: on colored natives in the colonies, in orphanages, in psychiatric hospitals and asylums for incurably ill, in prisons". And they continue to play important role in the present time too. Doctors experiment on patients, but also on healthy volunteers (he noted that between April and September 1947, Science published 5 studies on healthy people). The further development of medical science; grafts of organs and tissues, the progress of genetics, the manipulation of the mind, will increase even more the need for a truly efficient regulation of experimentation on humans (Fleck 1948b).

Among many consensual proposals developed by Fleck in his 1948 article, one may stand out as disturbing: the possibility of conducting dangerous experiments on prisoners condemned to death. Fleck explained that experiments on prisoners, even those made

32 Fleck was among the first to show that scientific facts are always situated and reflect the "thought style" of scientists who produce them (Fleck 1935/1979). 
with their consent, are morally dubious, because prisoners are not always truly free to refuse. But, he added, "prisoners legally condemned to death, can be given a possibility of rehabilitation by agreeing to a dangerous medical experiment, and providing in this way important services to society. They should be pardoned if they survive" (Fleck 1948b). Fleck's proposal is shocking for present-day sensibilities. The death penalty was abolished in Europe a generation ago. If one categorically rejects the state's right to kill people in cold blood, the idea that healthy people can be deliberately infected with mortal diseases, or undergo highly dangerous medical procedures, is distressing. ${ }^{33}$ The death penalty was, however, perfectly acceptable in a post-war Europe, and many people were executed in post-war Poland, a country caught in a brutal struggle between a Communist power and opponents of the regime. Does this make Fleck's proposal more acceptable?

It is difficult to know today what the reaction of Polish doctors who read Fleck's paper was. Historical parallels may, indicate, however, that the existence of the death penalty is not sufficient to legitimate dangerous experiments on condemned criminals, perhaps because such experiments produce an unacceptable confusion between medicine and the law. In 1886, after his triumphal public demonstration of the efficacy of his rabies vaccine, Pasteur wrote to his great admirer, the Brazilian emperor Dom Pedro II: "If I were a king or an emperor, or even the president of a republic, that's how I'd use my right to forgive prisoners condemned to the death penalty. I'd offer to the advocate of the condemned prisoner, just before the execution, the possibility to choose between imminent death and an experiment which would consist of injection of preventive anti-rabies serum, in order to produce an individual resistant to rabies" (Louis Pasteur, Ecrits, vol. V). Dom Pedro immediately rejected Pasteur's suggestion, which embarrassed his followers as well: enthusiasm for science does not justify morally doubtful acts.

Fleck's proposal to conduct dangerous medical experiments on people condemned to death implicitly assumed that such experiments will always be grounded in doctors' aspiration to reduce human suffering. Tadeusz Kielanowski, a physician and philosopher of medicine, questioned this assumption. In his comments on Fleck's paper, Kielanowski explained that one cannot automatically suppose that physicians who conduct experiments on human beings wish only or even mainly to help suffering people. A capacity to obtain a medical degree does not say much about moral qualities of a given individual. Doctors can conduct experiments on patients because they wish to advance their professional interests, or because of their hubris. Kielanowski had met ambitious and not very experienced physicians who devised new, dangerous therapies and rushed immediately to test them on sick people. The existing laws cannot prevent such practices or punish doctors responsible for them, even if the patient dies. Physicians who experiment on human beings are guilty of many sins, and, Kielanowki added, he was not speaking only about crimes committed by Nazi doctors (Kielanowski 1948,

33 Soldiers may be sent to accomplish very dangerous tasks, but, with the exception of suicide missions, they can always hope that they will survive. 
1292-1293 $3^{34}$ ). Kielanowski strongly supported Fleck's call for a rigorous regulation of experiments on human beings. He added that one should keep in mind that topics at the center of present-day public debates on such experiments are not always those that are the most important for patients or society. Supervision of experimentation on humans should not be limited exclusively to endeavors clearly labeled "clinical experiments." It should be extended to routine medical practice too, because the latter is often the site of unsound and morally doubtful experimentation (Kielanowski 1948). In spring 2020, in the midst of the COVID-19 pandemic and controversies on unproven therapies, some of which, such as hydroxychloroquine, gained the support of presidents Trump and Bolsonaro, the injunction to maintain high professional and ethical standards in clinical experimentation takes on a renewed urgency (Berlivet \& Löwy 2020; Wong 2020).

A similar injunction - to pay attention to the mundane, and not only to the exceptional - may be important for historians too. Some of the traits of clinical trials conducted in extreme conditions can be also found in routine medical practices. The efforts of ex-prisoners of Block 50 to produce narratives which isolate the production of the typhus vaccine from the other activities of the block's laboratory were a by-product of the distorted, barbarous universe of the Buchenwald camp. They resonate, however, with doctors' frequent wish to dissociate the potentially conflicting aspects of medical work (care of the sick, production of new knowledge, advancement of doctors' careers, financial considerations) and present each of them as belonging to a distinct and unrelated domain. Scientific research often proceeds through a purification process, as does the crafting of stories about such research. The conscious and unconscious aspiration to produce edited and "purified" narratives may be even stronger when these narratives deal with a problematic subject, such as experiments on human beings. Studying such experiments, one finds frequently only partial and fragmentary evidence: historians' claims should be modest. Modesty is not, however, tantamount to inefficacy. Historians may be unable to find out what had "really" happened in a given human experiment, but investigations which restitute the original complexity and messiness of such experiments open spaces for understanding, reflexivity and compassion.

\section{References}

Amsterdamska Olga, Bonah Christian, Borck Cornelius et al. 2008. „Medical Science in the Light of a Flawed Study of the Holocaust: A Comment on Eva Hedfors' Paper on Ludwik Fleck," Social Studies of Science 38:937-944. 
Balachowsky Alfred Serge. NN. Balachowsky's papers, BAL/1. Paris: Pasteur Institute Archives. The transcript in English available on http://www.yale.edu/lawweb/ avalon/imt/proc/01-29-46.htm

Balachowsky Alfred Serge. 1946. Testimony, Nuremberg trial, 29.1.1946.

Balachowski Alfred Serge. 1965 (January). „Block 46 au procès du Nuremberg,“ Patriote Resistant.

Bayle François. 1950. Croix Gammé contre Caducée. Berlin - Neustadt: Imprimerie Nationale.

Berlivet Luc \& Löwy Ilana. 2020. « Hydroxychloroquine Controversies: Clinical Trials, Epistemology, and the Democratization of Science," Medical Anthropology Quarterly (in press).

Fleck Ludwik. 1948. Persecution documents no. 2224 \& 2226, I.G. Farben trial in Nuremberg, February 12, 1948, reproduced in S. Werner, C. Zittel, \& F. Schmaltz (Eds.) 2007, Ludwik Fleck: Style myślowe i fakty: artykuły i świadectwa (pp. 358365). Warszawa: IFiS PAN.

Fleck Ludwik. 1946a. „Kilka spostrzeżeń i doświadczeń z dziedziny duru plamistego” [Some observations and experiments on typhus], Polski Tygodnik Lekarski 1:307309.

Fleck Ludwik. 1946b. „Swoiste substancje antygenowe w moczu chorych na dur plamisty" [Specific antigenic substances in the urine of typhus patients], Polski Tygodnik Lekarski 1:663-666.

Fleck Ludwik. 1946c. „Problemy naukoznawstwa”, Życie Nauki 1:335-336 (English version in R. Cohen \& T. Schnelle (Eds.) 1986, Cognition and Fact: Materials on Ludwik Fleck (pp. 113-127). Dordrecht: Reidel.

Fleck Ludwik. 1948a. "Comment of a Paper by Tadeusz Tomaszewski, Psychological Studies on Ex-prisoners of Concentration Camps," Reports of Philosophical and Psychological Society of Lublin 1947-1948. Reproduced in S. Werner, C. Zittel, \& F. Schmaltz (Eds.) 2007, Ludwik Fleck: Style myślowe i fakty: artykuły i świadectwa (pp. 296-297). Warszawa: IFiS PAN.

Fleck Ludwik. 1948b. „W sprawach doświadczeń lekarskich na ludziach”, Polski Tygodnik Lekarski [Polish Medical Weekly] 35.

Fleck Ludwik. 1979 (Orig. 1935). Genesis and Development of a Scientific Fact. Chicago: Chicago University Press.

Fleck Ludwik. 2007. „On Buchenwald: Comment on F. Bayle’s Book Croix gammée contre caducée," reproduced in S. Werner, C. Zittel, \& F. Schmaltz (Eds.) 2007, Ludwik Fleck: Style myślowe i fakty: artykuły i świadectwa (pp. 306-311). Warszawa: IFiS PAN.

Foot Michael. 1966. SOE in France. London: Her Majesty Stationary Office.

Hedfors Eva. 2008. "Medical Science in the Light of Holocaust: Departing from a Postwar Article by Ludwik Fleck," Social Studies of Science 38(2):259-283. 
Hessel Stéphane. 1997. Danse avec le siècle. Paris: Seuil. Available online on http://www. hg.goe.ni.schule.de/projekte/dora/jahrestag/shfz.doc (last accessed on April 2020).

Kielanowski Tadeusz. 1948. «W sprawie artykułu prof. dra Flecka o doświadczeniach lekarskich na ludziach», Polski Tygodnik Lekarski 43:1292-1293.

Lutowski Jerzy. 1950. „Co to jest leukergia: Rozmawiamy z profesorem Fleckiem”, Po Prostu 18(104), reproduced in S. Werner, C. Zittel, \& F. Schmaltz (Eds.) 2007, Ludwik Fleck: Style myślowe i fakty: artykuły i świadectwa (pp. 317-319). Warszawa: IFiS PAN.

Narbutowicz Barbara. 2007. Letters from L. Fleck, reproduced in S. Werner, C. Zittel \& F. Schmaltz (Eds.) 2007, Ludwik Fleck: Style myślowe i fakty: artykuły i świadectwa. Warszawa: IFIS PAN.

Pasteur Louis. 2012. Écrits scientifiques et médicaux. Paris: Flammarion.

Schnelle Thomas 1986. "Notes from a conversation with Eugen Kogon," reproduced in S. Werner, C. Zittel, \& F. Schmaltz (Eds.) 2007, Ludwik Fleck: Style myślowe i fakty: artykuły i świadectwa (pp. 399-400). Warszawa: IFiS PAN.

Seaman Anna, testimony. Thomas Schnelle Archiv, Das Ludwik Fleck Zentrum am Collegium Helveticum, Zurich, TSA, D 14/1.

Waitz Robert \& Ciepielowski Marian. 1946. "Le typhus experimental au camp de Buchenwald", La presse médicale, from 18 May: 322-324

Weindling Paul J. 2000. Epidemics and Genocide in Eastern Europe 1890-1945. Oxford: Oxford University Press.

Weindling Paul J. 2001. "The Scientist as Survivor: Ludwik Fleck and the Holocaust," La lettre de la Maison Française d'Oxford 13, Trinity Term: 85-96.

Weindling Paul J. 2009. "The Fractured Crucible: Scientific Survival, and the Defense of Ludwik Fleck," in J. Fehr, N. Jas, \& I. Löwy (Eds.), Penser avec Ludwik Fleck - Investigating a Life Studying Life Sciences (pp. 47-62). Zurich: Ludwik Fleck Centre/Collegium Helveticum.

Wong Julia. 2020. “Hydroxychloroquine: How an Unproven Drug Became Trump’s Coronavirus' Miracle Cure," The Guardian, April 07, 2020. 


\title{
Ilana Löwy (Paris)
}

\section{Typhus in Buchenwald: Can the Story Be Told?}

\begin{abstract}
Ludwik Fleck is known today primarily as pioneer in the social study of scientific knowledge. However, during World War II he was a prisoner in Buchenwald, where he and other prisoners produced a typhus vaccine for the Nazis, and where he witnessed murderous experiments on human beings. After WW2, Fleck was accused by one of the prisoners who had participated in the vaccine production at Buchenwald of collaborating, either deliberately or due to lack of imagination, with the Nazi experiments. This article critically examines this accusation and its well-documented rebuttal by Fleck. It argues that while sometimes, especially when dealing with emotionally fraught issues, it may be difficult to establish what precisely took place at a given time and site, it is important to restore the original complexity and messiness of past events - in order to open spaces for understanding, reflexivity and compassion.
\end{abstract}

Keywords: Ludwik Fleck; human experiments; Buchenwald; typhus; Nuremberg trials.

Ethics in Progress (ISSN 2084-9257). Vol. 11 (2020). No. 1, Art. \#1, pp. 4-19.

Creative Commons BY-SA 4.0

DOI:10.14746/eip.2020.1.1 